\begin{tabular}{ccc}
\hline Mournals & $\begin{array}{c}\text { MARKETING AND BRANDING } \\
\text { RESEARCH }\end{array}$ & $\begin{array}{c}\text { INDUSTRIAL } \\
\text { MANAGEMENT } \\
\text { INSTITUTE }\end{array}$ \\
\hline
\end{tabular}

\title{
Analyzing the Juridical reasons of corporate social responsibility in private sector with an emphasis on the necessity of paying Khums
}

\author{
Reza Payandeh ${ }^{1 *}$, Mohammad Taha Kharratha ${ }^{2}$ \\ ${ }^{1}$ M. A. Student in Public Policy, Imam Sadiq University, Tehran \\ ${ }^{2}$ M. A. Student in Private Law, Imam Sadiq University, Tehran
}

Keywords:

Corporate Social Responsibility, Legal Entity, Khums, Necessity of Khums

Correspondence:

Payandeh@isu.ac.ir

\section{Abstract}

Organizations act as a link between the individual and society and are considered as one of the most basic components of social configuration of modern human beings which need society and people to ensure access to basic survival needs. On the other hand, these organizations as legal entities are responsible to be responsive towards the demands of society. The concepts such as corporate social responsibility and its dimensions and components have attracted the attention of many researchers. This study was conducted to analyze the juridical reasons of corporate social responsibility in private sector with an emphasis on the necessity of paying Khums. According to Ahl al-Bayt view, the necessity of Khums in business profitability and all human revenues is simply proved, but the extent of paying Khums has been generally stated and it has not mentioned who should pay this Khums. It is taken directly from the religious texts that the focal point is the profit which is obtained from trade and business and therefore khums is not related to special group or individual. It is not necessary to oblige the tradesman to any religious orders because Khums is obligatory on possessions/profits owned by a person which are achieved from private organizations or not. Regarding the importance of financial gain and the required conditions related to Khums, It seems that everyone who has a profit or revenue will be obliged to pay Khums whether he has real or legal entity.

(C)AIMI Journals

\section{Introduction}

Organizations as a powerful phenomenon which are based on social needs can impact on the communities positively and negatively through their decisions and actions. Therefore, they should be responsible towards the consequences of their decisions and actions and maintain moral considerations (Gholipour, 2005). Organizations play mediating role between the 
individual and the society and are considered as one of the most important fundamental elements of modern human beings social configuration. These organizations need community and people to ensure their continued survival that's why the leading organizations give top priority to products production and delivery of modern social services in their research and developmental activities. It was once thought that the organizations are only responsible towards their shareholders and employees, but with population growth, resource constraints, and growing importance of international competition new approaches have emerged that corporate social responsibility can be considered as the results of these developments or changes (Chavoshbashi, 2010). To benefit from the infrastructures and environmental, social, scientific profits, the organizations should properly consider the corporate social responsibility and the respect to consumers' right in their strategic plans (Sheikh \& BeiseZee, 2011). According to corporate social responsibility definition, organizations as well as real individuals are considered as members of society and therefore are responsible for their surrounding environment. In addition to understanding the importance of improving their economic and social performance, organizations should set measures to promote the people's standards of living standards in their agenda. Carroll (1999) mentioned that about 8 to 9 per cent of investments annually are allocated to corporate social responsibility in the United States. In preliminary studies conducted on this base, it was proved that corporate social performance of organizations is considered as an important issue for public policy making process, managers, and stakeholders these days. Agle, Mitchell, and Sonnenfeld (1999) considered the management of relations between shareholders, employees, customers, government, and local committees as one of important component of corporate social responsibility within the organization. Social activity may be led to a gain in organizations, although it is not considered as a sufficient reason to apply corporate social role. The concepts of business ethics and organization's social responsibility increase the legitimacy of organizational measures, improve business performance and competitive advantage, and bring success to organization (Rahmanseresht, Rafeyi, \& Koosha, 2009). A manager who is equipped with social insight in addition to technical skills and political knowledge can be successful in his work. Public interest honoring and attention to social needs are two important issues that the managers should give them importance. In this era, a successful manager is not only who pays attention to the technical and economic goals but also it refers to a person who provides the overall objectives of an organization besides the public interest and general community policies (Alvani, 1996). In the social system hierarchy, governmental structures, public and private organizations, and high- status individuals enjoy the highest attainable level of rights and obligations. As they have some expectations of the people, people also have some other expectations of their own authorities such as taking sensible and effective approaches, accepting their performance outcomes and achievements, being responsive to their inefficient performances, and finally improving them.

\section{Formation Processes of Corporate Social Responsibility}

In the 1950s, Howard Baron (1953) proposed the concept of corporate social responsibility by asking what the reasonable responsibilities of owners towards society are and then discussed the necessity to access the goals, values, and considered community policies. 
Therefore, the corporate managers realized that there is a direct relationship between them and community. In the early $1960 \mathrm{~s}$, business ethical issues were taken into account and then many businesses that their products jeopardize the environment and people's safety were banned by the citizens. In this decade, Walton and Dutton (1967) proposed variables and models and defined different aspects of social responsibility. According to his perspective, a new concept regarding to the corporate social responsibility formed that refers to the intimate relationship between the organization and society on the one hand, and top managers' understanding of the relationship between the pressure groups to access their strategic objectives on the other hand. Bowen (1953) also considered to the political importance of the issues in companies legislation for the first time and moreover to the concept of social responsibility. In the 1970 s, different definitions related to the concept of corporate social responsibility developed at the same time as the concept of public businesses cooperation in humanitarian organizations formed and achievement profits especially long-term profits in accordance to the needs of society were diagnosed. In this decade, some significant changes in the United States and the UK employment laws were done and four different varieties or models of social responsibility including social accounting, social indicators, and social audits were introduced to improve social functioning. In the $1980 \mathrm{~s}$, the researchers attempted to clarify the relationship between corporate social responsibility and reputation enhancement, competitive position improvement, sales growth, and achieving profitability. In the 1990s, a new development in the field of definitions related to social responsibility took place. Hopkins (1998) defined that corporate social responsibility is concerned with treating the stakeholders both within a firm and outside of the organization ethically or in a socially responsible manner. Woodward (1999) introduced a three-part concept consisting of people, planet, and profit announced. In his approach, he paid more attention to things that are useful for environment and the performance of an organization. Muir (2001) believed that a deeper understanding is the reason of behavioral commitment in organizations and determining the moderation level of social responsibility in this decade. Jamali and Mirshak (2007) stated that the reason of corporate social responsibility failure in some organizations is lack of knowledge and experience. Therefore, the 21 st century could be called the course of rules and standards related to corporate social responsibility (Shafei \& Ahmadi, 2012).

\section{Definition of Corporate Social Responsibility}

In literature review, there is no unified definition of corporate social responsibility and in most of definitions the ethical, behavioral, and social aspects of corporate social responsibility can be found as common feature in all of them. Holm and Watts (2000) introduced corporate social responsibility as the human face of the highly competitive world of commerce. They believed that there is a continuous relationship between corporate social responsibility and business, ethical behavior, and economic development in order to improve the quality of work life. McWilliams and Siegel (2001) argued that corporate social responsibility refers to the legal, ethical, and commercial expectations that the society has of business. Robbins (2005) stated that corporate social responsibility management is beyond the economic profitability, and its focus is on improving and maintaining the social welfare programs for society members. He argued that we should consider the needs of both internal 
and external users of organization. Barney and Griffin (1992) defined corporate social responsibility as a set of obligations and commitments that the organizations should conduct to preserve, care, and help to the society in which it operates. They also refers to the duties on the behalf of private sector organizations in a sense that they do not have an adverse effect on social life in which they work. These duties generally refer to the tasks such as preventing environmental pollution, avoiding discrimination in hiring, preventing immoral and unethical activities, and informing the consumers about the quality of products. Furthermore, Ebert and Griffin (2012) believed that ethical values concern more to the behavior of each individual within the organization while corporate social responsibility deals with the way organizations behave with their employees, shareholders, investors, clients, and stakeholders in general. Nowadays, corporate social responsibility has a much broader sense compared to the past. In the modern sense, corporate social responsibility considered as a program or tool in economical, political, and social sectors to create and promote public confidence in economic enterprises for investment. It is also a method in economical management which enables enterprises and helps them to develop in three dimensions including economy, environment, and society. Moreover, corporate social responsibility creates opportunities for economic enterprises to propose the concepts which are of the utmost importance for the society. In business, it also helps enterprises to consider themselves as a member of society (Ghaheri, 2010; Khalili Araghi \& Yaghinlu, 2004; Robins, 2005).

\section{Source of Corporate Social Responsibility}

These days, many organizations are involved in social activities that some of them support the works of art, religious, and environment. Organizations may provide some interests and facilities for employees so that they provide a ground for their social activities. Consumers who may have much experience may receive services from organizations which are not possible for new consumers. Organizations usually enter into social activities to increase their profitability but sometimes managers also cited other reasons for their social activities; for example, some companies support the social activities to maximize shareholder wealth, but there are some other reasons than profit which make organizations to participate in social activities. Some of them believe that social activities in organizations are a common form of investing which occurres to reach long-term values and goals. Accordingly, there is no legal prohibition to the organizations' managers for doing activities to maximize the organizations' values, achieving their short-term gains, and maximizing shareholders' interests. In fact, the managers' task is making a balance among multiple objectives. Although, making balance among issues such as maximizing organizations' long-term values and having a short-term view towards maximizing the rate of return shareholders is a very complex task. Social decision making as well as other types of decisions are possible only if these two conditions are possible. The first condition states that shareholders should have ability to impose a level of discipline to the management. and the second one mentions that an organization should legally work in a competitive environment. Although, we cannot assume these two conditions as a certain fact (Garner, 2004; Holme \& Watts, 2000; Kerr, Janda, \& Pitts, 2009) emphasized that corporate social responsibility belongs only to human beings as a person not a member of organization 
because only human begins are responsible and spend time on issues such as environmental protection which its results will help people's welfare. They can support the projects which require no personal cost voluntarily. Before addressing this issue directly, it is necessary to consider some points. First, the nature of the organization has changed greatly with the recent changes in trade structure. In organizations, the nature of these changes is in a way that awards a corporate social responsibility beyond the organizational levels to their individuals. Second, there is a belief that the organizations with corporate social responsibility result from certain recent trends towards moral responsibility and therefore individuals who are under the influence of uncontrollable forces such as environmental, social, psychological, and genetic forces cannot take the responsibility for their actions. Ronald Coase (1988) believed that the high transaction costs of negotiating contracts are the cause of creating organizations. In an ideal competitive economy, all goods and services can be exchanged between the producer and the consumer through contractual agreements, but the continuation probability for these interactions increases transaction costs in practice. Therefore, these two parties create longterm agreement in organizations. Then, the existence of these agreements is assessed in different ways by law. One of them is a joint-stock company and in which the shareholders have limited liability. Changes which are made in technology sectors and other fields lead to a deformation of international trade and to anarchic economic relations. These days, exchange displaces with the traditional model of employer-employee relations; therefore, based on this framework, the concept of landlordism, the employer has the legal right to control his employees. Thus, the organizations not individuals have liability, and this is escaping way from personal responsibilities. In fact, accepting personal responsibilities towards society is a sign of honesty and maturity (Kerr et al., 2009).

\section{Conceptual Implications of System Hierarchy}

Organizations are considered as independent, self-contained, autonomous entities and known for their independent identities. The organizational identity is independent concept and is apart from the identity of members. Despite the multiple definitions of the system concept, all of them have two common characteristics. First, system as a whole phenomenon is different from an entity which consists of a number of elements. Second, the relationship between elements should be included in any definition of system. Therefore, system is defined as an entity which consists of related interactive elements and this connection and interaction give totality to system. One of the most important features of system is its totality. Bertalanffy (1968) was the first person who proposed a holistic system approach on the basis that the whole is much more than just the sum of its parts. The whole system represents new qualities and its constituent elements do not have those qualities. Kenneth Boulding (1956) classified systems based on their hierarchy of complexity into free standing machinery systems, equivalent systems of the most evolved species, human systems and relying on works he had done in the field of public economics and system theory. The general criterion for classification is enhanced relationships and the degree of complexity which is achieved through movement from one level of growth to the next level. The higher levels inherit all features and properties of lower levels. Moreover, Boulding introduced some distinctive features for each of these levels. Organizations as social systems place at a higher level than 
human systems; therefore, they possess all the features of previous levels. The responsibility towards society is one of features of systems and its level changes from one level to another one.

\section{Conceptual Implication of Natural and Legal Characters}

Lawyers call an individual a character who possesses proper qualifications and rights. Individuals are categorized into two groups, namely natural and legal character. Natural character refers to the human beings generally. In the past, the human person was the central subject of human rights but these days he is considered as an advocate for it. A natural character has its own distinctive features such as name, residence, citizenship, marriage, divorce, birth, death, and inheritance. The legislator not only actively supports the individuals' interests but also supports the interests of groups and organizations in society. This supportive character tries to increase productivity and development in groups in order to not having any concern about their property and belongings. Abstract description of legal person or juristic personality is called legal characteristic (Jafari Langroudi, 1996, 1999) and a person who has legal characteristic is called spiritual person (Ansari \& Taheri, 2001). Based on social order, individuals who form each group or organization should not be in direct contact with their creditors and clients due to abnormalities in political and economic orders. Therefore, it seems essential to have groups which have their own rights and duties and assume distinctive personality profiles for their members (Safaee \& Ghasem Zadeh, 2003). The evaluation of legal entities' formation is not limited to human groups and furthermore considers the targeted profitable properties into account. In any case, the most important thing is a series of general common interests which are as social life realities, the law supports them, and recognizing dignity for their holders so that they could possess legal assets and enter into their legal life (Tabatabai Motameni, 1999). Accordingly, the legal person is a group of individuals who has common interests and engages in activities or a piece of properties with specific purpose which law recognizes right in respect of them and makes them as distinctive character (Safaei, 2006). There are different opinions about the exact nature of the legal entities since the principle in Iran's law is based on the qualifications of legal character except those which are related to real character according to article 588 of Iranian commercial code about real existence that Iranian lawyers have been accepted it as a credit entity (Jafari Langroodi, 1996, 1999, 2012). Therefore, legal characters can possess any type of properties and financial rights like real characters and act on their commitments (Emami, 1993). A detailed literature review represents that a legal character has all the rights and duties that the law recognizes in respect of individuals except natural rights and duties. Legal character has various forms and among them private law attracts the attention of current researchers.

\section{Juridical Reasons to Give the Organizations Identity}

The concept of legal character is not mentioned in available legal resources, existing laws, and legal reasoning, but other similar terms are used. One of these common terms is an Arabic word 'dhimmi' which means protected, agreement, liability, and treaty. It is a general term and refers to all entities which have responsibility and are obliged to do things whether 
they are human or not. According to the scholars of Usul-al-Figh, the human beings are distinctive from other creatures due to the rights which are for and against them and their duties and obligations.

Therefore, this term is used as an adjective with alive human as real characters and with nonhuman as legal characters (Safar, 1994). In western law, dhimmi means "property" which refers to all the financial rights and obligations (Katouzian, 1991). Property is considered as constitutive part of human nature and it consists of a set of assets and liabilities which unified with its owner. Property consists of three main characteristics namely being independent of its components, possessing rights and financial duties, and including human related concepts. There are some similarities and differences between property and dhimmi in principals of Islamic jurisprudence. Their similarity is placed in their overall direction, generality, and independence of its components. We should not consider that the relationship between dhimmi and property is equal because dhimmi has some components which are separated from property. Dhimmi consists of financial and non-financial concepts which refer to the qualifications of individuals while property refers to all financial rights and duties. Also, the originality of these two concepts is different. Dhimmi is not transferred to another person or people while property is transferred from dead person to his/her heirs (Katouzian, 1991;Law\& Martin, 2009). The transfer of financial dhimmi and separating it from its owner is not possible as long as he/she is alive. Therefore, dhimmi is considered as character and its owner as a legal person from the wise or legal legislators' perspectives. Accordingly, dhimmi only runs in financial field and cannot include the absolute meaning of dhimmi. As a result, only those private organizations and companies which have the ability to get their rights and duties are considered as independent legal character based on religious norms and principles of Islamic jurisprudence. There are two orientations about the concept of legal character among jurists, namely denial of legal personality and legal personality admission.

\section{Denial of Legal Character}

Some jurists do not recognize the concept of legal personality in it's entirely, some of them stated that seizures of funds in state banks without the permission of the judge or his legal representative are not permitted. This statement indicates that the bank has been identified as an independent person which can be the licensing source to transfer any assets seized by themselves. Some other such as Ayatollah Sistani does not accept the legal personality of the bank. They argue that the banks are not considered as the owners of their own properties to put them at the disposal of its borrowers. To get rid of this issue, the borrowers can get their intended amount from the bank as the unknown owner. Therefore, all such institutions are fully under the control of the Islamic ruler and do not have independence (Walker, 1980).

\section{Legal Personality Admission}

Some contemporary scholars such as Imam Khomeini acknowledged that all permitted bank transactions with Muslims can be considered correct whether it is governmental or not. It seems that all various transactions which are performed by banks such as transactions with Muslims are considered correct. Furthermore, government considers a special legal personality for such institutes apart from the personality of its members to do their business 
tasks according to certain standards. From Juridical perspective, legal personality is an accepted concept for religious holy sites such as mosques, churches, Kaaba, and admitted topics such as Emamat. Therefore, the reason to prove legal personality is not limited to the special time and should be accepted by trusting to the mental reasons of lawyers.

\section{Necessity of Khums}

Khums (one- fifth of gain) is considered as one of important Islamic economic and financial issues. With the advent of Islam, the legitimacy of khums was approved after descenting Surah Al-Anfal verse 41 in the Quran during the second year of Hijrah of Prophet Muhammad. There are two different viewpoints about the legitimacy of Khums including Khums as a right for specific groups and Khums as Islamic tax that is the dominant view among Shiite scholars. Generally, the payment of Khums has categorized into two different groups. First, it should go to his Messenger and near relative of the Messenger (Ahl al-Bayt) and whenever they are not present in the community, the ruler in Islamic society place in charge of them. Therefore, all current orders at their time are run in their absence. Second, it belongs to special groups such as

orphan, needy, and a person who has fallen away from his hometown and has no money to comeback it. The justification for belonging Khums to the first group is that it is used for maintaining security and promoting religious expression whether at the time of the Prophet or in the current era. The reason why Khums should be paid to the second group is their need. An important point that should be mentioned is that this financial resource should be allocated to the leadership positions of Islamic society and not for their personal use (Safar, 1994). Moreover, it is far from the thoughts that God make Khums and other financial resources available in possession of a single person.

\section{Definition of Khums}

There are two different approaches towards Khums, namely traditional and tax. Traditional approach states that Khums goes into Allah, his Messenger and Ahl al-Bayt, and orphans and needy of Bani-hashim while tax approach tries to highlight the social and economic aspects of Khums. Totally, the tax aspect of Khums as one of the main aspects of the tax system is emphasized. Based on the definitions of these jurists, Khums refers to the part of government revenues which is placed at the disposal of supreme leader of Islamic community to use it optimally in charitable activities, provide a proper ground for justice in society, and provide a brighter future for vulnerable groups in society. However, the sufficient attention is not paid to its economic and social dimensions. A number of contemporary scholars believe that the real owner of Khums is God and Prophet Muhammad and Imams take their own ownership from God. In other words, their ownership is validated and due to their leadership position. As a result, Khums is an instrument to run the justice and have a symmetrical distribution of income in society to support various social sectors including the vulnerable or needy persons which are contrary to the view that it belongs to the three groups including orphans, the needy, and the wayfarer. Ibn Joneid and Sunni Muslim scholars believed that the share of the needy, orphans, and the wayfarer does not allocate to the Sadat. It has an absolute meaning and meets the needs of all the non-Bani Hashim orphans and needy people. Ibn Joneid argued 
that there is not any reference in Surah Al-Anfal in the Quran which states that Khums goes to those needy, orphans, and the wayfarers who are Sayyid. Therefore, this concept is beyond his relatives and refers to some vulnerable persons in society. Finally, the level of financial need is a criterion for those who deserve to receive Khums. Therefore, the desirable criterion is the need of persons whether they are Sadat or not. The tax approach related to Khums is more compatible with Ibn Joneid's perspective because it is widely used in the provision of social benefits. A careful study of verses related to Khums, Zakat, and Anfal reflects the fact that almighty God determines Khums to run Islamic government and provides the basic needs of poor people whether they are Sadat or not through spending Islamic government funds. Khums as tax is used in establishing an Islamic government to help establish justice and prevent injustice and aggression in social dimension. Khums as a public finance acts such as a tool to provide justice and prevent injustice and aggression. However, the traditional approach to the issue of Khums increases inequality and social class differences. Therefore, it has criticized for some reasons such as weakness of its document and spread of ant-Shia ideas. Khums should be divided into two parts including the share of current Imam and the share of poor descendants of the Prophet. The share of current Imam should be delivered to the fully qualified jurist or used for the purpose which he has allowed. One of the most important things that a fully qualified jurist can apply Khums is public benefit works such as culture, health, construction and development, and environmental protection. This requires a precise mechanism to preserve social order and deliver all the costs which are going to spend for public benefit activities to the fully qualified jurist. Therefore, it is his duty to establish public order and receive all tax funds to spend for society benefits.

\section{Khums on the Surplus or Profit of the Income}

Khums on the surplus or profit of the income refers to the one fifth of annual gain. Khums is called to the benefit which is more than annual costs and acquires through legitimate activities. Nowadays, the profit of income or earning has a central role in Islamic Taxation System and its complete payment influences on all social groups. If the Islamic government receives this Islamic tax as a profit, it will receive considerable income and can provide the credit of many construction and service projects. Therefore, Khums is the most aappropriate tool for the redistribution of income and wealth and preventing wealth goes hand in hand among the rich. The most important features of Khums which can outline are stability, inclusiveness and breadth, deduction of consumption and production costs, credibility in the fiscal year, income tax, and tax reporting for worship place. Khums on the surplus or profit is considered as special tax which is different from the so-called tax; for instance, Islamic tax drives its legitimacy from a divine source- God and considers the rights of Allah and the rights of people simultaneously. The reasons why Khums is necessary in Islamic societies are investigated from two aspects namely Quran and Sunnah. In Quran, for example Surah AlAnfal verse 41, the term gains (al-ghanā'im) takes its root from the word "Ghanam" which means achieving a benefit or profit whether this profit obtains from fighting against the unbelievers and winning them or working and doing efforts in mines. This word has semantic extension in different books based on their context of use. Sheikh al-Mofid argued that 
Khums is obligatory for every type of trophy which is gained in war with unbelievers or any type of profit which is obtained through commerce, agriculture, and craftsmanship and is more than the annual cost of per person. Imam Sadegh (Peace be Upon Him) mentioned that if a person takes advantage of his work every day, this advantage will consider as trophy.

\section{Conclusion}

This study analyzed the juridical reasons of corporate social responsibility in private sector with an emphasis on the necessity of paying Khums. A qualitative investigation of statements related to Khums shows the necessity of paying Khums for the profit or the surplus of the income which are obtained by human beings. Studies in hadith methodology which focus on business and trade have stated that it is not important that who pays Khums whether it is a private organization or individual / group. Moreover, the person who pays Khums (religious tax) does not require to be necessarily bound by the religious orders because Khums is paid on some kinds of property not the possessor whether the possessor is a minor or an adult, male or female, sane or insane, free or busy (69). Therefore, according to traditions, it seems that anyone who gains profit or revenue should pay Khums whether that person is a real character or a legal character. Finally, statements about Khums are considered as religious one while the points related to legal characters are not considered as religious ones. They are considered as economic statements that their social-tax aspect should be assumed. In this paper, we consider organization as an entity which does not require to be bound by religious orders and statements; therefore, Khums is not a mere individual statement.

\section{References}

Agle, B. R., Mitchell, R. K., \& Sonnenfeld, J. A. (1999). Who matters to CEOs? An investigation of stakeholder attributes and salience, corporate performance, and CEO. Academy of Management Journal, 42, 507-525.

Alvani, S. M. (1996). General management. Tehran: Nei Publications.

Ansari, M., \& Taheri, M. A. (2001). Encyclopedia of private law (1 ${ }^{\text {st }}$ ed.). Tehran: Mehrab Fekr.

Barney, J. B., \& Griffin, R.W. (1992). The management of organizations: Strategy, structure,and behavior. Boston: Houghton Mifflin.

Bertalanffy, L. V. (1968). General systems theory: Foundations, development, and applications. New York: George Braziller.

Boulding, K. (1956). General systems theory: The skeleton of science. Management Science, 2(1), 197-208.

Bowen, R. H. (1953). The social responsibilities of the businessman. New York: Harper \& Row.

Carroll, A. B. (1999). Corporate social responsibility. Business \& Society, 38(3), 268-295.

Chavoshbashi, F. (2010). An introduction to social responsibility in the organization level. Journal of Social Responsibility, 2, 35-55.

Coase, R. H. (1988). The firm, the market, and the law. Chicago: University of Chicago Press.

Ebert, R. J., \& Griffin, R. W. (2012). Business essentials ( $9^{\text {th }}$ ed.). Upper Saddle River, NJ: Pearson.

Emami, H. (1993). Civil rights. Tehran: Islamiyah Publication.

Garner, B. A. (2004). Black's law dictionary ( $9^{\text {th }}$ ed.). New York: Thomson Reuters Business Press.

Ghaheri, R. (2010). Corporate social responsibility and necessity of attention to it. Journal of Corporate Social Responsibility, 61(3), 109-158.

Gholipour, A. (2005). Sociology of organizations. Tehran: Samt Publication.

Holme, R., \& Watts, P. (2000). Corporate social responsibility: Making good business sense. Geneva: World Business Council for Sustainable Development. 
Hopkins, M. (1998). The planetary bargain: Corporate social responsibility comes of age. London: Macmillan.

Jafari Langroodi, M. J. (1996). Encyclopedia of civil rights and trade. Tehran: Rasta Foundation.

Jafari Langroudi, M. J. (1999). Discussion of law terminology. Tehran: Ganje Danesh.

Jafari Langroudi, M. J. (2012). Consistent in terminology rights (4 ${ }^{\text {th }}$ ed.).Tehran: Ganje Danesh Publications.

Jamali, D., \& Mirshak, R. (2007). Corporate social responsibility (CSR): Theory and practice in a developing country context. Journal of Business Ethics, 72(3), 243-262.

Katouzian, N. (1991). Introduction to law. Tehran: Sahami Enteshar Publication.

Kerr, M., Janda, R., \& Pitts, C. (2009). Corporate social responsibility: A legal analysis. Markham, Ontario: LexisNexis.

Khalili Araghi, M., \& Yaghinlu, M. (2004). Highlights of corporate social responsibility in organizations. Tadbir, 15(1), 6466.

Law, J., \& Martin, E. (2009). Oxford dictionary of law ( $7^{\text {th }}$ ed.). New York: Oxford University Press.

Rahmanseresht, H., Rafeyi, M., \& Koosha, M. (2009). Social responsibility and post- organizational ethics. Tadbir, 204, 2226.

Robins, F. (2005). The future of corporate social responsibility. Asian Business \& Management, 4, 95-115.

Safaee, H., \& Ghasem Zadeh, M. (2003). Civil law: People and retards ( $9^{\text {th }}$ ed.). Tehran: SAMT Publication.

Safaei, S. H. (2006). The civil rights foundation. Tehran: Mizan Publication.

Safar, M. J. (1994). Legal personality ( $1^{\text {st }}$ ed.). Tehran: Dana Publication.

Shafei, R., \& Ahmadi, K. (2012). Corporate social responsibility, concepts, theories, models,and applications. Tehran: SAMT Publication.

Sheikh, S. U., \& Beise-Zee, R. (2011). Corporate social responsibility or cause related marketing? The role of cause specificity of CSR. Journal of Consumer Marketing, 28(1), 27-39.

Steurer, R., \& Astrid, K. (2009). Business-society relations in Central-Eastern and Western Europe: How those who lead in sustainability reporting bridge the gap in corporate (social) responsibility. Scandinavian Journal of Management, 25(1), $23-36$

Tabatabai Motameni, M. (1999). Administrative law (6 $6^{\text {th }}$ ed.). Tehran: SAMT Publication.

Walker, D. M. (1980). The Oxford companion to law. Oxford: Claredon Press.

Walton, R., \& Dutton, J. (1967). The management of interdepartmental conflict: A model and review. Administrative Science Quarterly, 14(1), 73-83.

Woodward, C. (1999). Key opportunities and risks to New Zealand's export trade from green market signals: Report to the Ministry for the Environment. Wellington: Woodward Clyde. 